\title{
Mangrove Cover in Jakarta: An Output of GNRM Program on Strengthening Lecturers and Students Awareness to the Sustainability of Jakarta Coastal Environment
}

\author{
Aryo Sahid Sujiwo ${ }^{1} \quad$ Untung Setiyo Purwanto ${ }^{2}$ Raihan ${ }^{3}$ \\ Mulki Siregar $^{4} \quad$ Achmad Sutrisna $^{5}$ \\ GNRM Team of Universitas Islam Jakarta \\ Jakarta, Indonesia
}

\begin{abstract}
Jakarta is very vulnerable to erosion and tidal flooding. Mangrove forest on the Jakarta coastal has a very important role because it can reduces the damage caused by seawater tidal flooding and erosion. However, the existence of mangrove forests is threatened by various natural factors, human activities and a combination of both. Given the important role of mangroves for the city, data and information on temporal changes in the distribution of mangrove cover in this area need to be monitored annually to evaluate changes in cover holistically. Therefore, this study was conducted to detect changes in the spatial and temporal distribution of mangroves on the Jakarta coastal. Landsat 7 ETM satellite image data from 2014 to 2018 were analyzed using medium resolution combined with visual interpretation and literature review to detect changes in mangrove areas. Mangrove forest cover was estimated at 111.58 hectares in 2014 and decreased to 103.84 hectares in 2018. That means Jakarta has lost 7.74 hectares over 4 years. This review article will also discuss the main factors that influence, changes in area, the impact of Jakarta Bay reclamation on North Jakarta's mangroves.
\end{abstract}

Keywords: GNRM program, mangrove cover, Jakarta coast

DOI: $10.7176 / \mathrm{JESD} / 12-18-06$

Publication date:September $30^{\text {th }} 2021$

\section{Introduction}

The vision of the President of the Republic of Indonesia in the National Medium-Term Development Plan 20202024 is "The Realization of an Advanced Indonesia that is Sovereign, Independent, and Has a Personality Based on Mutual Cooperation." Meanwhile, there are nine missions of the President, which are called Nawacita, namely Improving the Quality of Indonesian Humans; Productive, Independent, and Competitive Economic Structure; Equitable and Equitable Development; Achieving a Sustainable Environment; Cultural Progress that Reflects the National Personality; Enforcement of a Corruption-Free, Dignified, and Reliable Legal System; Protection for All Nations and Providing Security for All Citizens; Clean, Effective, and Reliable Government Management; and Local Government Synergy within the Framework of the Unitary State.

To realize the vision and mission, the President has set five main directions as a strategy, namely Human Resource Development; Infrastructure development; Simplification of Regulations; Simplification of the Bureaucracy; and Economic Transformation. In the first directive, namely Human Resources Development, there are three strategies, namely Basic Services and Social Protection, Productivity and Character Development. One of the strategies in character building is Mental Revolution and Pancasila Ideology Development. Mental Revolution is a change in the way of thinking to respond, act, and work. The basic idea of Mental Revolution is to build the soul of the nation, namely the spirit of independence, the spirit of freedom to achieve progress. The spirit of Mental Revolution is aimed at reviving the spirit of progressive change for the Indonesian nation.

Mental Revolution was developed as a national movement to change perspectives, attitudes and behavior that is oriented towards progress through internalizing the Strategic Values of Mental Revolution Instrumental (NSIRM) in individuals, communities, families, social institutions, up to state institutions. The NSIRM includes the values of integrity, work ethic, and mutual cooperation which are noble values of the nation's culture. In the 2020-2024 period, the development of the Mental Revolution specifically targets three main areas, namely Education, Governance, and Social Systems. This is set out in the 2020-2024 RPJMN as a National Priority for Mental Revolution and Cultural Development. Mental Revolution must be a strategy for human and cultural development that is continuously internalized in the development system, so that it becomes systemic and experiences civilization in daily behavior.

Mental Revolution is described in a more holistic and integrative way that relies on: Mental Revolution in the education system by emphasizing the values of integrity, work ethic and mutual cooperation, as well as character education in learning; Mental revolution in governance by cultivating the values of transparency and accountability; and Mental Revolution in the social system by cultivating the noble values of the nation's culture in family institutions and interactions between citizens. Mental Revolution is also strengthened through efforts to promote and preserve culture, strengthen religious moderation to strengthen harmony; and improve a culture of 
literacy, innovation, and creativity for the realization of a knowledgeable, innovative, creative, and characterized society, including encouraging the involvement of the public (non-government) in the effort to make GNRM active. The implementation of GNRM is represented through five movements, namely the Serving Indonesia Movement, the Clean Indonesia Movement, the Orderly Indonesia Movement, the Independent Indonesia Movement, and the United Indonesia Movement. GNRM encourages the initiative of all change agents to work together to change conditions for the better and more advanced according to people's expectations. All components of the nation are expected to act as agents of change which is a tangible form of GNRM activity (Kemenko PMK, 2021).

One of the nine missions of the President is Achieving a Sustainable Environment. This mission shows that the President is very concerned with the implementation of the concept of development as well as paying attention to the importance of environmental conservation, including the coastal environment. This is in line with Law No. 27 of 2007 which mandates that Coastal Areas and Small Islands are part of the natural resources bestowed by God Almighty and are assets controlled by the state, which need to be preserved and utilized for as much as possible. Great prosperity of the people, both for the present generation and for generations to come. The law also states that the Coastal Zone and Small Islands have a high diversity of potential natural resources, and are very important for social, economic, cultural, environmental, and national development, and as a buffer for national sovereignty, therefore they need to be managed sustainably and with a global perspective, taking into account the aspirations and participation of the community, and the nation's values based on national legal norms.

Coastal areas have many ecosystems. One of the ecosystems that grows in coastal areas is the mangrove ecosystem, apart from the estuarine ecosystem, seagrass beds, and coral reefs, which have many ecological, economic and social functions. The mangrove ecosystem is an ecosystem whose plant communities are salt tolerant. Mangrove ecosystems have ecological and economic functions. The ecological function of the mangrove ecosystem is as a coastal protector from abrasion, flood control, a place for marine biota to live for shelter, foraging for food, spawning and nurturing, as a source of food for existing species, anchoring toxic substances, carbon sinks, while the economic function of Mangrove ecosystem is a mangrove ecosystem that can be used to produce medicinal ingredients, as a producer of food such as fish, shrimp, crab shells, as well as a place for recreation and tourism (Asyiawati \& Akliyah, 2014).

In general, the purpose of this activity is to support the government's plan through the Coordinating Ministry for Human Development and Culture and the Indonesian Chancellor's Forum in realizing the National Mental Revolution Movement. Through this activity, the Islamic University of Jakarta intends to become one of the centers of change in the mental revolution movement to bring about changes in attitudes, behavior, ways of thinking, perspectives, and ways of working of the campus academic community to realize an advanced, independent, fair and prosperous Indonesia. In particular, the purpose of this activity is to increase the awareness of lecturers and students on the importance of preserving the coastal environment.

\section{Introduction}

The vision of the President of the Republic of Indonesia in the National Medium-Term Development Plan 20202024 is "The Realization of an Advanced Indonesia that is Sovereign, Independent, and Has a Personality Based on Mutual Cooperation." Meanwhile, there are nine missions of the President, which are called Nawacita, namely Improving the Quality of Indonesian Humans; Productive, Independent, and Competitive Economic Structure; Equitable and Equitable Development; Achieving a Sustainable Environment; Cultural Progress that Reflects the National Personality; Enforcement of a Corruption-Free, Dignified, and Reliable Legal System; Protection for All Nations and Providing Security for All Citizens; Clean, Effective, and Reliable Government Management; and Local Government Synergy within the Framework of the Unitary State.

\subsection{GNRM Program in brief}

Mental Revolution has an important position and plays a central role in national development. The character and mental attitude must be changed for the better with the encouragement of the government and the community movement. Discipline mentality, work ethic, honesty, obeying laws and regulations, diligent, and persistent and mutual cooperation are the characters and mental attitudes needed to create an advanced, modern, superior, and competitive nation-state, so that it can compete with other countries. other. Mental Revolution as a social and cultural movement must affirm Indonesia as a pluralistic nation-state with a diversity of tribes, customs, cultures, and religions, which form a unity in diversity: Bhinneka Tunggal Ika. The strength of the Indonesian nation lies in differences and diversity, not in equality and uniformity. To strengthen Bhinneka Tunggal Ika, awareness as a pluralistic nation-state must be instilled early in the family, strengthened in the education system, and continuously nurtured and cared for in the social-social system.

GNRM is based on Pancasila as the ideal foundation of the state and the 1945 Constitution of the Republic of Indonesia as the constitutional basis and Trisakti as the conceptual basis. In its implementation, GNRM is 
based on operational foundations, namely Presidential Instruction Number 12 of 2016 concerning GNRM, Presidential Regulation Number 18 of 2020 concerning the National Medium-Term Development Plan (RPJMN) 2020-2024 and Decree of the Coordinating Minister for Human Development and Culture Number 20 of 2020 concerning National Task Force on Mental Revolution for 2020-2024.

GNRM is a movement that involves all components of the nation by strengthening the real role of state administrators and all elements of society. The implementing elements of this movement or stakeholders consist of 5 (five) actors/agents of change (pentahelix), namely state administrators (executive, legislative, judicial) both at the center and in the regions, the world of education, the community, the business world and the media. GNRM is systemic, collective, and massive which is largely determined by the commitment and concrete actions of all stakeholders. The next five stakeholder groups become nodes of change through concrete actions in their respective environments, as well as increasing public awareness of the achievements or impacts of the Mental Revolution development carried out. The exemplary state administrators accompanied by consistent law and rule enforcement practices are expected to generate change initiatives that involve the world of education, business, society and the media.

The implementation of GNRM is based on 8 (eight) principles of the movement, namely it is a social and cultural movement to encourage Indonesia's progress, the values developed are aimed at regulating social life and public morality, not private morality, starting with a value attack program to change the behavior of all parties quickly and concretely, the movement program is designed in a user-friendly, popular and part of the lifestyle, is cross-sectoral and cross-target, collaborative in nature that provides a space for participation for state administrators, the world of education, the community, the business world and the media, state administrators ensure the sustainability of GNRM implementation, and its achievements/impacts can be measured. The eight principles of GNRM indicate serious efforts to make fundamental changes to the character, personality and behavior of the nation.

The policy directions in the development of the Mental Revolution are described in the form of the 20202024 RPJMN Priority Activities, which are carried out in a coordinated and integrated manner by involving the responsible Ministries/Agencies, Ministries/Supporting Agencies and Local Governments along with other stakeholders. The Coordination, Synchronization and Control (KSP) of the implementation of these Priority Activities is coordinated by the Coordinating Ministry for Human Development and Culture and the GNRM National Task Force. In particular, the Government has developed 5 (five) Movement Programs designed to help trigger the strengthening of Integrity, Work Ethic, and Mutual Cooperation. The five programs are the Serving Indonesia Movement, the Clean Indonesia Movement, the Orderly Indonesia Movement, the Independent Indonesia Movement, and the United Indonesia Movement.

In accordance with Presidential Instruction Number 12 of 2016 concerning GNRM, the Coordinating Minister for Human Development and Culture is tasked with coordinating, synchronizing, and controlling the implementation of GNRM, compiling and establishing Roadmaps and General Guidelines, establishing and assigning a GNRM Task Force, and reporting the results of GNRM implementation to President. In order to realize the Inpres, the Coordinating Minister for Human Development and Culture has established a National Task Force. In order for the implementation of GNRM to be optimal, each Ministry/Agency needs to form a Task Force for the Ministry/Agency which is determined through a Decree of the Minister/Head of Institution. In the context of implementing GNRM in the regions, the Minister of Home Affairs coordinates the formation, implementation, development, and reporting of the GNRM task force in each province and every district/city. For the implementation of GNRM in the regions, the Governors, Regents, and Mayors form a Regional Task Force which is determined through a Decree of the Governor, Regent, and Mayor (Kemenko PMK, 2021).

\subsection{Mangrove Ecosystem Services on the coast of Jakarta}

Mangroves are one of the ecosystems in the coastal area of Jakarta, in addition to seagrass ecosystems, coral reefs, peat, and other ecosystems. The literature shows that coastal ecosystems offer many benefits to humans. The benefits or services that can be provided by these ecosystems are called ecosystem services (Fisher et al., 2009). The benefits of this mangrove are enormous, not only for humans and the economy. In addition, mangroves also provide benefits for the growth of flora and fauna. In general, the ecosystem services provided by mangroves can be categorized into four, namely provisional, regulatory, cultural and supporting services (De Groot, 2012).

\subsubsection{Provisional Services}

Mangrove provisional services can be explained as the benefits obtained by the community from coastal ecosystems in the form of materials (MEA, 2005). For example, people can catch fish, crabs, fruit or wood in the mangrove forest. Mangroves are one of the places to catch fish because many animals make mangroves as nursery, habitat protection and breeding ground (Sukardjo, 2004). Furthermore, mangroves can also produce many products that can be produced from processing with mangrove raw materials, such as tofu, tempeh, lunkhead, candy, various crackers, crackers, sticks, chips, to soap (Sri and Dedin, 2015). 


\subsubsection{Regulating services}

Regulatory services are the benefits derived from the regulation of ecosystem processes (MEA, 2005). For example, mangroves can reduce damage during a large tsunami/hurricane. In other words, mangroves can reduce the loss of life and repair costs after a large tsunami/storm. In addition, Mangroves can absorb the global challenges faced by many countries today. That is related to global warming. Mangroves, forests and other ecosystems such as peat, coral reefs and seagrass can absorb carbon dioxide. These ecosystems can absorb carbon dioxide which is a source of global warming problems and can directly reduce the impact of global warming (Dahdouh-Guebas et al., 2005).

In the future, mangroves can also be used in world carbon trading where carbon dioxide producing countries, especially industrialized countries, will pay compensation for their carbon dioxide expenditure to countries that have ecosystems that can absorb carbon dioxide. For example, five hamlets in Jambi Province, Indonesia have received carbon trade compensation funds for having protected forests in these hamlets (Djaenudin, 2016).

Figure 1 shows that mangroves can absorb far more carbon dioxide than tropical rain forests (Murray et al, 2000). Therefore, Indonesia has many opportunities in the future to receive carbon trading compensation money. A concrete example above, Indonesia has just received compensation money from the forest. So it is possible that Indonesia can receive compensation money from the mangroves. In addition, mangroves also function as water purifiers for rivers and seas (Williams, 2013).

2.2.3 Cultural services

Cultural services are services related to the benefits that humans get through entertainment, reasoning development, relaxation and spiritual reflection (Hein at al, 2006). Cultural services can also be said to be a bonus that comes along with public awareness of the sustainability of an ecosystem. Based on field observations, mangrove forests can be used as ecotourism that can increase the income of coastal residents. These non-material products/benefits from coastal ecosystems are cultural services. Mangrove forests in Jakarta can be an ecotourism vacation spot for people around Jakarta and even international tourists. In addition, mangrove forests can also be used as a research center for all fields and mangroves can also be a source of inspiration, culture and spirituality (de Groot, 1992).

2.2.4 Supporting Services

Supporting services are services that are necessary for the production and maintenance of all other ecosystem services (MEA, 2005). For example, mangroves provide living space for plants and animals. Protected mangroves will maintain biodiversity that supports the sustainability of other ecosystem services. Mangroves have a very high number of species and make mangroves known as one of the biodiversity hotspots. Mangrove forests can make Indonesia rich in biodiversity (Malik, 2015). There are at least 12 animals that live in the mangrove forest. Various types of birds, storks, ducks, shrimps live in the mangrove forest. In addition, various types of swamp plants can be found here. The existence of various types of mangroves and the diversity of animals that live in them will maintain genetic diversity (Costanza and Folke, 1997; Ronnback, 2007)

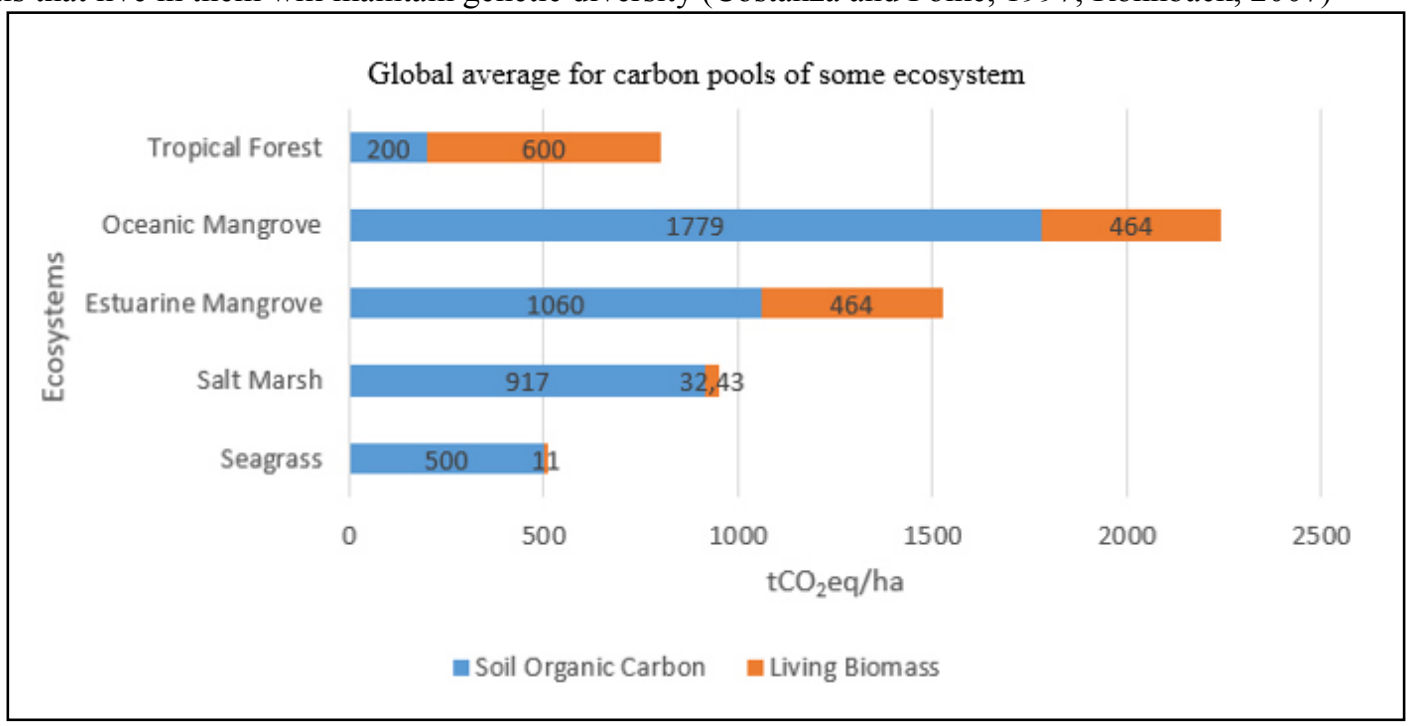

Figure 1. Comparison of the amount of carbon that can be absorbed by several ecosystems

(Source: Murray et al, 2000) 


\section{Methodology}

\subsection{Research sites}

This study focuses on mangrove forests located on the coast of Jakarta, Jakarta Province, Indonesia. In fact, there are two locations of mangrove forests on the coast of Jakarta, namely mangrove forests on the coast of North Jakarta and mangrove forests on the Thousand Islands. This study focuses on mangrove forests located on the coast of Jakarta. In particular, the purpose of this study is to determine the extent of mangroves in the coastal areas of Jakarta from 2015 to 2018. This location has become the focus of attention of researchers considering that mangrove forests on the coast of Jakarta are highly threatened by various human activities. The map of the research location can be seen in Figure 1.

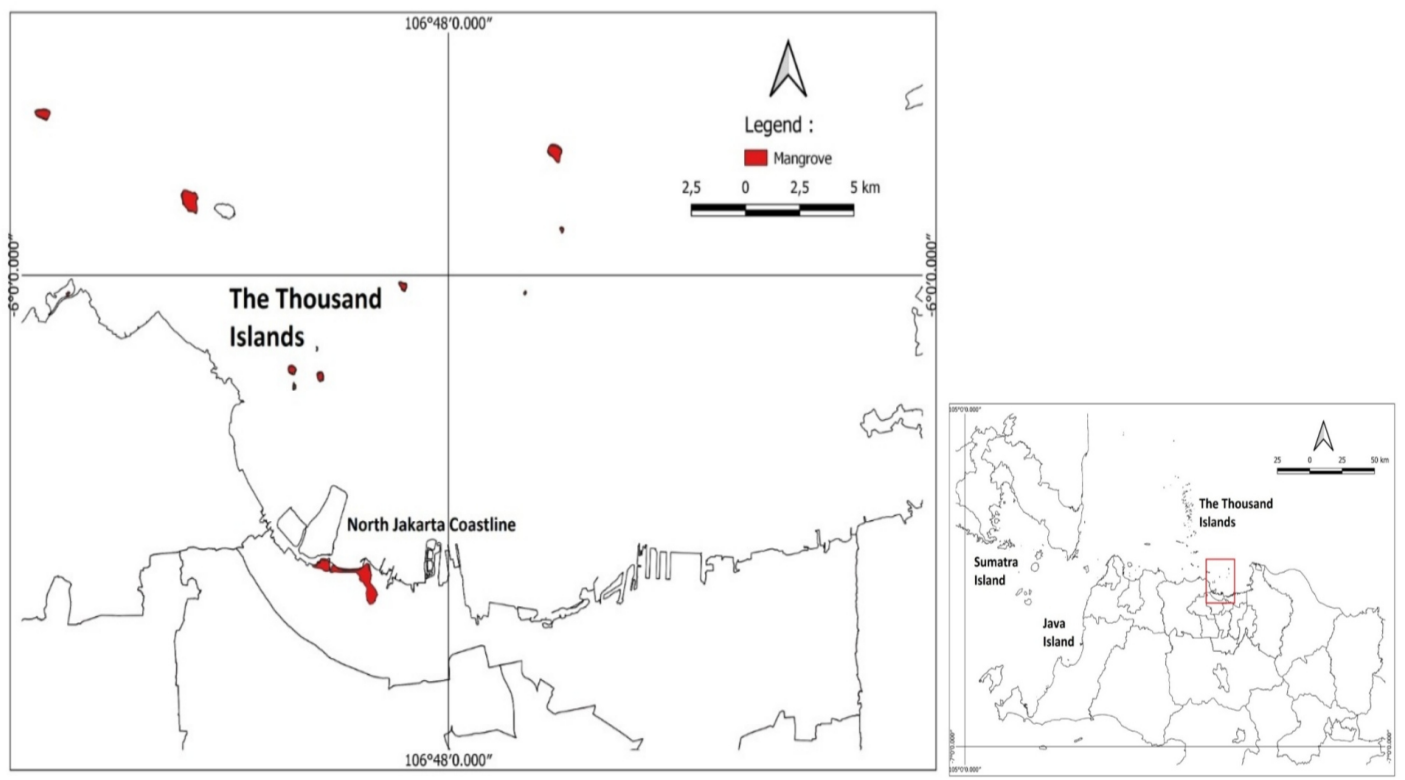

Figure 2. Research location (Source: Indonesian geographic information agency)

\subsection{Method of collecting data}

The vast source of mangroves located on the coast of North Jakarta comes from land use and land cover from the Ministry of Environment and Forestry of the Republic of Indonesia (KLHK). This research will focus on 2014 2018 data using Landsat 7 ETM medium resolution imagery and with a sensing resolution of 1:250,000. Digital image analysis is done by interpreting the visual image. This is done to provide an initial picture in the field survey, determining the number of land cover classes and types of land cover classes in the research area. All of these data were obtained from LULC KLHK. Analysis of land cover change using GIS software. GIS is an information system that combines map elements (geographical) and information contained in the map data to analyze and process spatial data (Manongga et al., 2009). Furthermore, this study conducted a literature study to examine the results of previous research that had been carried out in the coastal area of North Jakarta.

\section{Results and Analysis}

\subsection{General condition of mangrove ecosystem in coastal areas of Jakarta}

The results of the digital image analysis show that the majority of mangrove species in the coastal area of Jakarta are secondary mangrove species. Premier mangroves are defined as mangroves that have never been touched by logging. While secondary mangroves are mangroves that have experienced logging. This shows that in general, mangroves in the coastal areas of Jakarta have experienced previous logging. In addition, all mangroves in North Jakarta are coastal mangroves.

For mangrove species, it is known that the majority of mangrove species that grow in the coastal areas of Jakarta, especially in the Pantai Indah Kapuk area are Avicennia marina, Rhizophora mucronate and Rhizophora stylosa. Mangroves of Exocaeria agallocha, Acanthus illicifollius and Xylocarpus granatum species can also be found in the coastal areas of Jakarta, but are not dominant (Putri, 2015).

The types of mangroves that exist in the coastal area of Jakarta can provide a physical description of the habitat conditions there. The three types of mangroves in the coastal area of Jakarta have similarities. First, they grow well in mud-type sediments and can tolerate moderate-mud sediment types. Second, they can adapt to few waves with high tides inundating 20 to 40 times. Third, they can adapt to different salinity levels and can tolerate high soil salinity during the dry season and low salinity during the rainy season (Bengen, 2004). Avicennia 
marina can survive in fine-textured sediment types, which have high salinity organic matter values (Barkey, 1990). Rhizophora mucronate is inundated all the time, the dominant species is Rhizophora mucronate (Hong and San, 1993; Kusmana, 2015).

Mangrove forest is the main ecosystem that supports important life in coastal and marine areas. In addition to having an ecological function as a provider of nutrients for aquatic biota, spawning and nurturing various kinds of aquatic biota, retaining coastal abrasion, hurricane winds and tsunamis, absorbing waste, preventing sea water intrusion, mangrove forests also have high economic functions such as providing wood. , medicines, fishing gear and techniques. The functions of mangrove forests can be classified into three types, namely physical functions, ecological functions and economic functions. The physical functions of mangrove forests include: maintaining the stability of coastlines and riverbanks from erosion or abrasion, accelerating land expansion by absorbing mud deposits carried by currents into mangrove forest areas, controlling the rate of sea water intrusion so that the surrounding well water becomes fresher, protect the area behind the mangroves from waves, strong winds and tsunami hazards. Mangrove forest is a complex and distinctive ecosystem, and has a large enough carrying capacity for the surrounding environment. Therefore, the mangrove ecosystem is said to be productive and provides high benefits through economic and ecological functions. As an ecosystem and natural resource, the use of mangroves is directed at the welfare of mankind and to realize its sustainable use, the mangrove ecosystem needs to be managed and maintained (Lisna et al., 2017).

\subsection{Mangrove Extents and Distribution in the coastal of Jakarta}

In 2014, the results of a spatial analysis of the mangrove area in the coastal area of Jakarta showed that the mangrove area in the area was 111.58 hectares. This mangrove area did not change in 2015 . In 2016, the mangrove area in the coastal area of Jakarta decreased by 8.12 hectares to 103.46 . This mangrove area did not change until 2017. In 2018, the mangrove area in the coastal area of Jakarta experienced a slight increase of 0.38 hectares to 103.84 hectares. Changes in mangrove area can be seen in Figure 1. As shown in Figure 1, during the period 2014 to 2018, the area of mangroves on the coast of Jakarta has decreased by 7.74 hectares. The green area is the mangrove area in 2018 while the red shaded area is the mangrove area that has been lost.

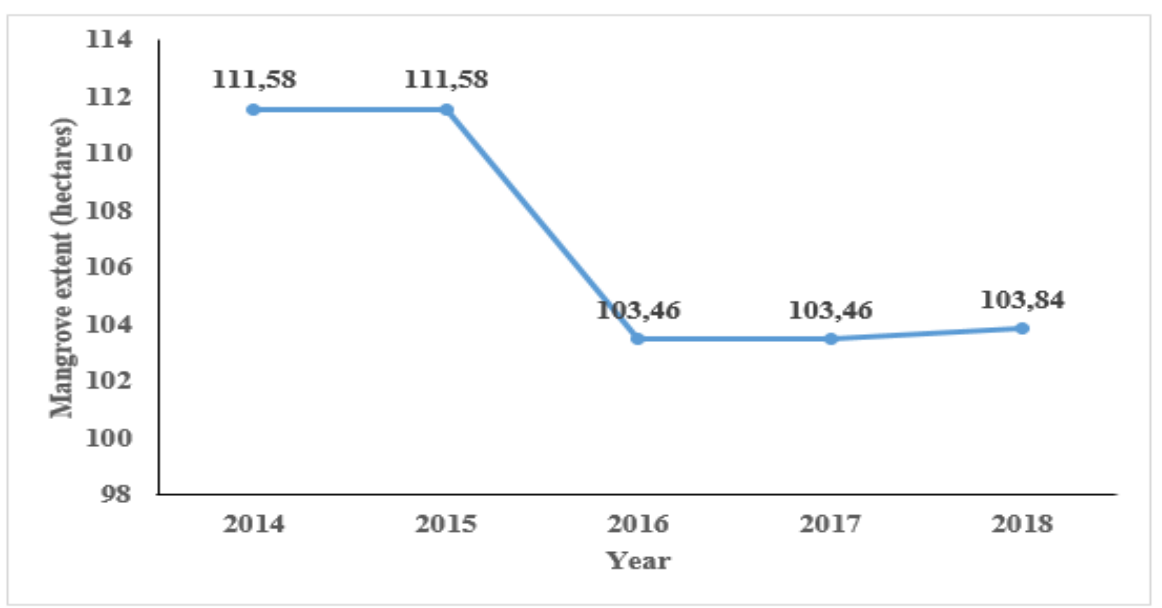

Figure 3. Research location (Source: Indonesian geographic information agency) 


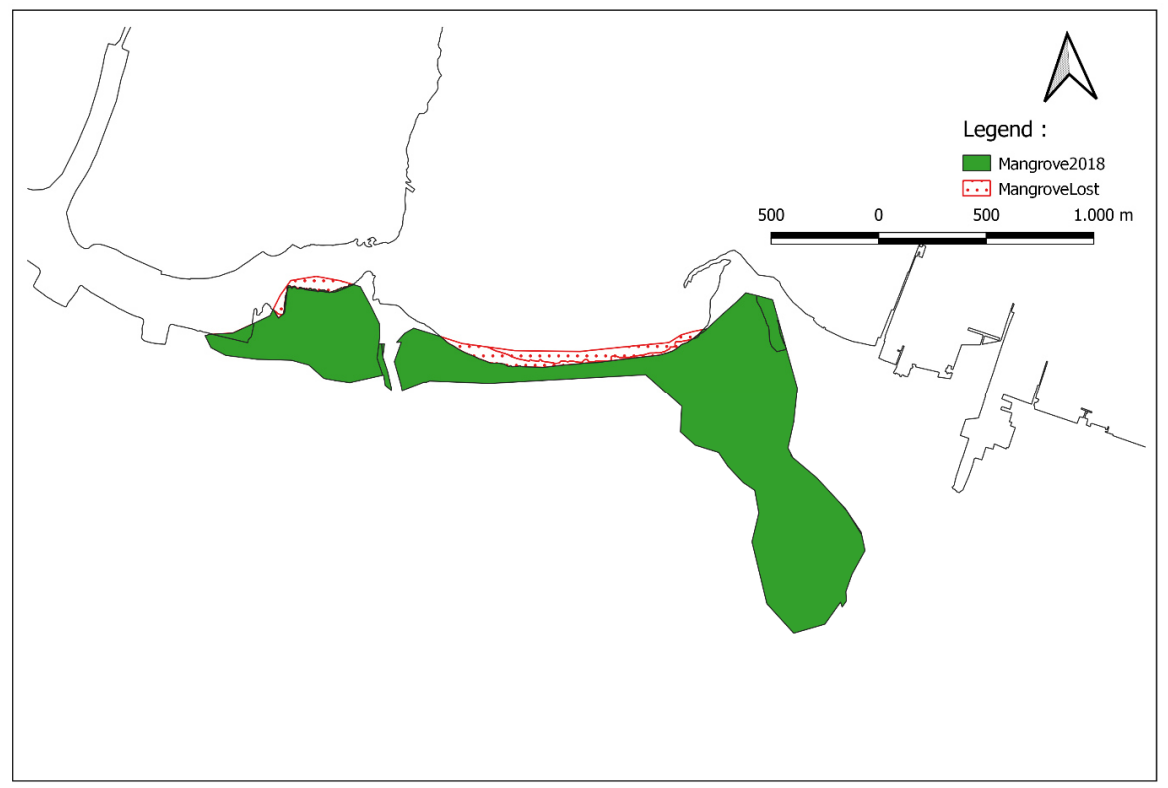

Figure 4. Mangroves extent in the coast of Jakarta (source: Ministry of Environment and Forestry)

\subsection{Factors affecting the mangrove ecosystem}

There are various factors that can affect the condition, distribution and structure of mangroves. These factors can come from anthropogenic factors (factors that arise due to the influence of human activities) and natural factors. In general, the factors that affect the mangrove ecosystem on the coast of Jakarta are as follows.

4.3.1 Climate Factor

All of Indonesia's territories are located around the equator and are in the tropics. Thus, mangrove forests can be found in many places in Indonesia. Indonesia is a country with the largest mangrove area in the world. Mangroves can be found throughout the tropics and subtropics. So that climate factors greatly affect the distribution of mangroves in the world (Giri et al, 2011). Furthermore, because there were no drastic changes in air temperature and soil temperature from January to December, no drastic physiological changes were found in mangroves in Indonesia.

The influence of climate on mangrove growth is through light, rainfall, temperature and wind. Light affects the process of photosynthesis, respiration, physiology, and the physical structure of mangroves. The intensity, quality, duration of lighting affect the growth of mangroves. Mangroves are long day plants that require high light intensity so they are suitable for living in the tropics. The annual growth rate of mangroves under the shade of sunlight is smaller and the mortality rate is the opposite. Light affects inflorescence and germination where plants outside the cluster (clusters) will produce more flowers because they receive more sunlight than plants in clusters. Rainfall affects such as the amount, duration, and distribution of rain affecting the development of mangrove plants, rainfall that occurs affects air conditions, water temperature, water and soil salinity. Temperature plays an important role in physiological processes (photosynthesis and respiration). Wind affects the occurrence of waves and currents. Wind is an agent of pollination and seed dissemination so that it helps the reproduction process of mangrove plants (Alwidakdo et al., 2014).

Monsoons also affect mangroves. The monsoon that brings cold air can also cause changes in the height, growth and size of mangrove trees. In addition, strong winds during the monsoon will increase the rate of evaporation, lowering air and water temperatures. This will affect the formation of mangroves. Strong winds will also increase mangrove litter (Hong and San, 1993). Waves and currents can change the structure and function of the mangrove ecosystem. In locations that have fairly large waves and currents, mangrove forests usually experience abrasion, resulting in a reduction in forest area (Alwidakdo et al., 2014).

Strong waves and storms also affect mangrove growth. Therefore, it is not recommended to reforest mangroves during the stormy season and big waves. This will damage the newly planted mangroves. However, this does not apply to the mangrove species Aegiceras corniculatum and Rhizophora stylosa, in fact a large storm will cause the formation of the mangrove to be better. Although mangroves are halophytes (salt tolerant species) they require a certain amount of fresh water for maximum growth. Rain will regulate the amount of salt concentration in the soil and mangroves (Hong and San, 1993).

4.3.2 Hydrological Factor

Another factor that affects the mangrove ecosystem is the hydrological factor, including the tidal factor. Tides 
are the movement of rising and falling sea levels caused by the attractive force between the earth, moon and sun. In addition to these attractive forces, meteorological and oceanographic influences also play a role in the formation of tidal characteristics, so that on each earth's surface there is a sea level position that varies from place to place and from time to time. Tides are influenced by wind, rainfall and river flow (Amalina et al., 2019). The tides that occur in mangrove areas greatly determine the zoning of plant and animal communities associated with the mangrove ecosystem. In detail, the effect of tides on mangrove growth is explained as follows. The duration of tides in mangrove areas can affect changes in water salinity where salinity will increase at high tide and vice versa will decrease at low tide. Changes in salinity that occur as a result of the long tide is a limiting factor that affects the horizontal distribution of species. The mass transfer of water between fresh water and sea water affects the vertical distribution of organisms. Meanwhile, the structure and fertility of mangroves in an area that has diurnal, semi-diurnal, and mixed tide types will be different. Species composition and distribution of inundated areas differ according to tide duration or inundation frequency (Alwidakdo et al., 2014). Table 1 presents several types of tides and their description

Table 1. Types of tides

\begin{tabular}{|l|l|}
\hline \multicolumn{1}{|c|}{ Tidal Types } & \multicolumn{1}{|c|}{ Definition } \\
\hline Diurnal tide & $\begin{array}{l}\text { There is one high tide and one low tide in one day with a tidal } \\
\text { period of } 24 \text { hours } 50 \text { minutes }\end{array}$ \\
\hline Semi diurnal tide & $\begin{array}{l}\text { There are two high tides and two low tides with almost the same } \\
\text { height and the tides occur sequentially regularly in one day. The } \\
\text { average tidal type is } 12 \text { hours } 24 \text { minutes }\end{array}$ \\
\hline $\begin{array}{l}\text { Mixed tide prevelailing } \\
\text { semidiurnal tide }\end{array}$ & $\begin{array}{l}\text { In one day there are two high tides and two low tides, but the height } \\
\text { and period are different }\end{array}$ \\
\hline $\begin{array}{l}\text { Mixed tide prevelailing } \\
\text { diurnal tide }\end{array}$ & $\begin{array}{l}\text { In this type, in one day there is one high tide and one low tide, but } \\
\text { sometimes for a while there are two high tides and two low tides } \\
\text { with very different heights and periods }\end{array}$ \\
\hline
\end{tabular}

(Source: Triatmodjo, 1999)

In the coastal area of Jakarta, the type of tidal that occurs there is a mixed tide prevelailing diurnal tide type. The duration of the tides and the duration of the tides The structure and fertility of mangroves in an area will have different types of species and distribution of areas depending on the type of tides in the area.

Mangroves that have a tidal amplitude (the difference in height between high and low tides) also affect the development of mangroves. Mangroves with a large tidal amplitude will widen the channel, minimizing seed and propagule settlement. minimizing mangrove seed and propagule settlement. The tidal amplitude off the coast of North Jakarta is only 1 meter, so this tidal range is not very significant in mangroves (Amalina et al., 2019).

The influence of ocean currents can also cause differences in mangrove species, fruit, seeds and propagules. All mangroves off the coast of North Jakarta receive the same current from the Java Sea. So that no striking differences in mangrove species were found among the mangroves in the research location. Several other factors, such as the alluvium content carried by fresh water to the mangrove area, also play a role in the growth of mangroves. Only areas that contain sufficient fresh water and alluvium that allow mangroves to grow (Hong and San, 1993).

3. Other Factors

Another anthropogenic factor that affects the mangrove ecosystem is the disposal of industrial, industrial, and agricultural waste into the river. Jakarta has 13 rivers that pass through large factories around Jabodetabek which empties into Jakarta Bay.

Salinity, $\mathrm{pH}$ will also affect the zoning of mangrove vegetation. Clean water quality and free of harmful substances also play a role in maintaining the health of mangroves. However, there are several factors that cannot be distinguished whether this is due to natural or anthropogenic causes due to the impact of global warming and widespread changes in human activities, for example, flooding that inundated the area around the mangroves. Is this flood a result of rising sea levels or due to changes in artificial structures around the mangroves (Mughofar et al, 2018). 
Table 2. Factors affecting mangroves growth

\begin{tabular}{|l|c|}
\hline \multicolumn{1}{|c|}{ Factor } & Description \\
\hline 1. Climate & \\
a. Drastic changes in air temperature & Not significant \\
b. monsoon & Significant \\
c. Frost & There is not any \\
d. Wind & Significant \\
e. Rainwater & Significant \\
f. Wave & Significant \\
\hline 2. Hydrology & \\
a. Ups and down & Not significant \\
b. Current influence & Not significant \\
c. Salinity & Significant \\
d. beach erosion & Significant \\
\hline
\end{tabular}

One of the factors that influence the distribution of mangrove forests is the availability of suitable habitats for each type of mangrove and tides. Tides have a direct or indirect influence on the development of the mangrove forest itself and the surrounding waters. Tidal movements are known to play a role in seed dispersal and seed growth, but have little role in the life of mature trees. The tidal height in coastal areas related to the topography of the mangrove forest floor will greatly affect the occurrence of mangrove zoning. The literature reveals that the growth and development of each type of mangrove is consistently related to the type of substrate, elevation and openness, so that the specification of the place of growth has a dominant influence on the type of community and its allies (Pramudji, 2000).

The tolerance of mangrove species to the salinity range also has an influence on the demand for mangrove forests. For example, Avicennia sp. is a genus that has the ability to tolerate a wide range of salinity, even in general this species is often found growing in coastal areas that have high salinity. This species is usually associated with Sonneratia sp. and Rhizophora stylose. Meanwhile, Brugguiera sp., Rhizophora apiculata, Xylocarpus granatum and Ceriops tagal species generally grow in areas with salinity below 25 permil. Meanwhile, the Aegiceras corniculatum species which are usually associated with Heritiera litoralis, Nypa futicans, Acrostihum aureum and Achantus ilicifolius grow in areas with low salinity or close to fresh water (Pramudji, 2000).

\section{Concluding Remark}

Mangrove forest that grows in the coastal area of Jakarta is one of the natural resources that has several special properties. The specificity of the mangrove forest is due to the very specific location of the mangrove forest, its unique ecological role, and the potential for high economic value. Mangrove forest is a natural resource that can be restored, so it requires proper handling, especially to prevent the destruction of these natural resources and to ensure the preservation of the present and the future. Mangrove ecosystems are distributed throughout Indonesia, especially along the east coast of Sumatra, the north coast of Java, the west and east coasts of Kalimantan, protected bay landscapes in Sulawesi, small islands in Maluku, and the south coast of Papua. Mangroves grow in muddy coastal landscapes, sheltered bays, deltas, and small islands. Until now, Indonesia is still the country with the largest mangrove in the world, although deforestation and mangrove degradation continue to occur (Rahadian et al., 2019). Thus, the mangroves that grow in the coastal areas of Jakarta need to be protected by all stakeholders. This article aims to raise the awareness of lecturers and students towards environmental conservation, especially the mangrove ecosystem on the coast of Jakarta.

\section{Acknowledgement}

We express our appreciation and gratitude to the Coordinating Ministry for Human Development and Culture (Kemenko PMK) and Indonesian Chancellor's Forum (FRI) for providing the opportunity for the Jakarta Islamic University to participate in the 2021 GNRM program.

\section{References}

Alwidakdo, A., Azham, A., \& Kamarubayana, L. (2014), "Studi Pertumbuhan Mangrove Pada Kegiatan Rehabilitasi Hutan Mangrove Di Desa Tanjung Limau Kecamatan Muara Badak Kabupaten Kutai Kartanegara", Jurnal AGRIFOR, 13 (1), 11-18

Amalina, A.D., Atmodjo, W., \& Pranowo, W. S. (2019). Karakteristik Pasang Surut di Teluk Jakarta Berdasarkan Data 253 Bulan. Jurnal Riset Jakarta, 12(1), 25-36

Asyiawati, Y., \& Akliyah, L. S. (2014). Identifikasi dampak perubahan fungsi ekosistem pesisir terhadap lingkungan di wilayah pesisir kecamatan muaragembong. Jurnal Perencanaan Wilayah dan Kota, 14(1), 1- 
13

Barkey, R. 1990. Mangrove Sulawesi Selatan (Struktur, Fungsi dan Laju Degradasi), Prosiding seminar Keterpaduan Antara Konservasi dan Tata Guna Laha Basah di Sulawesi Selatan. LIPI-Pemda Sulawesi Selatan

Bengen, DG, 2004. Ekosistem dan Sumberdaya Alam Pesisir dan Laut serta Prinsip Pengelolaanya. Pusat Kajian Sumberdaya Pesisir dan Lautan. IPB. Bogor.

Costanza, R., Folke, C., 1997. Valuing Ecosystem Services with Efficiency, Fairness and Sustainability as Goals. Island Press, Washington, DC, pp. 49-70

Dahdouh-Guebas, F., Jayatissa, L. P., Di Nitto, D., Bosire, J. O., Seen, D. L., \& Koedam, N. (2005). How effective were mangroves as a defence against the recent tsunami?. Current biology, 15(12), 443-447

De Groot, R., Brander, L., Van Der Ploeg, S., Costanza, R., Bernard, F., Braat, L., ... \& Van Beukering, P. (2012). Global estimates of the value of ecosystems and their services in monetary units. Ecosystem services, 1(1), 50-61

De Groot, R.S., 1992. Functions of Nature: Evaluation of Nature in Environmental Planning, Management and Decision Making. Wolters-Noordhoff, Groningen.

Djaenudin, D., Lugina, M., Ramawati, G. K., Indartik, M. A. P., \& Astana, S. (2016). Perkembangan Implementasi Pasar Karbon Hutan di Indonesia. Jurnal Analisis Kebijakan Vol, 13(3), 159-172.

Fisher, B., Turner, R. K., \& Morling, P. (2009). Defining and classifying ecosystem services for decision making. Ecological economics, 68(3), 643-653

Giri, C., Ochieng, E., Tieszen, L. L., Zhu, Z., Singh, A., Loveland, T., ... \& Duke, N. (2011). Status and distribution of mangrove forests of the world using earth observation satellite data. Global Ecology and Biogeography, 20(1), 154-159

Hein, L. et al. (2006), "Spatial scales, stakeholders and the valuation of ecosystem services", Ecological Economics, 57(1), 209-228

Hong, P.N., \& San, H.T. (1993). Mangroves of Vietnam. Iucn, Bangkok, Thailand

Kemenko PMK (2021), "Rancangan Peta Jalan Dan Pedoman Umum Gerakan Nasional Revolusi Mental (Gnrm) Tahun 2021-2024”, Coordinating Ministry for Human Development and Culture

Kusmana, C. (2015). Integrated sustainable mangrove forest management. Jurnal Pengelolaan Sumberdaya Alam Dan Lingkungan, 5(1), 1-6.

Lisna, L., Malik, A., Toknok, B. (2017), "Potensi Vegetasi Hutan Mangrove Di Wilayah Pesisir Pantai Desa Khatulistiwa Kecamatan Tinombo Selatan Kabupaten Parigi Moutong”, Warta Rimba, 5(1), 63-70

Malik, A., Fensholt, R., \& Mertz, O. (2015). Mangrove exploitation effects on biodiversity and ecosystem services. Biodiversity and Conservation, 24(14), 3543-3557.

Millennium Ecosystem Assessment (MEA). (2005). Ecosystems and Human Well-being: Synthesis. Washington, DC: Island Press

Mughofar, A., Masykuri, M., \& Setyono, P. (2018). Zonasi dan komposisi vegetasi hutan mangrove pantai Cengkrong desa Karanggandu kabupaten Trenggalek provinsi Jawa Timur. Jurnal Pengelolaan Sumberdaya Alam dan Lingkungan (Journal of Natural Resources and Environmental Management), 8(1), 77-85.

Murray, B. C., Jenkins, W. A., Sifleet, S., Pendleton, L., \& Baldera, A. (2010). Payments for blue carbon potential for protecting threatened coastal habitats, Policy Brief NI PB 10-05. Nicolas Institute for Environmental Policy Solutions, Duke University

Pramudji (2000), "Hutan Mangrove Di Indonesia: Peranan Permasalahan Dan Pengelolaannya, Oseana, 25(1), $13-20$

Putri, Lestari., Yulianda, Fredinan., \& Wardiatno, Yusli. (2015). Pola zonasi mangrove dan asosiasi makrozoobenthos di wilayah Pantai Indah Kapuk, Jakarta. Bonorowo Wetlands, 5(1), 29-43.

Rahadian et al (2019), "Tinjauan Historis Data Dan Informasi Luas Mangrove Indonesia, Media Konservasi, 24(2), 163-178

Ronnback, P.C.B.I.L., 2007. The Return of ecosystem goods and services in replanted mangrove forestsperspectives from local communities in Gazi Bay, Kenya. Environ. Conserv. 34, 313-324

Sri, D., \& Dedin F, R. (2015). Pengembangan Produk Olahan Mangrove dan Perikanan di Kawasan Pantai Wonorejo Surabaya, Prosiding Seminar Nesearch Month", http://eprints.upnjatim.ac.id/7013/2/Sri_Djajati_V.pdf

Sukardjo, S. (2004). Fisheries associated with mangrove ecosystem in Indonesia: a view from a mangrove ecologist. BIOTROPIA-The Southeast Asian Journal of Tropical Biology, 23(1), 13-39

Triatmodjo, B. (1999). Teknik pantai. Penerbit Beta Offset. Yogyakarta

Williams, C. O., Lowrance, R., Bosch, D. D., Williams, J. R., Benham, E., Dieppa, A., ... \& Williams, R. G. (2013). Hydrology and water quality of a field and riparian buffer adjacent to a mangrove wetland in Jobos Bay watershed, Puerto Rico. Ecological Engineering, 56, 60-68. 